\title{
Diurnal Variation in the Diuretic Effects of Nitrendipine in Saline Loaded Rats
}

\author{
Akio Fujimura, Hiroyuki Kajiyama, Tsuyoshi Shiga, \\ Kyo-ichi Ohashi and Akio Ebihara \\ Department of Clinical Pharmacology, Jichi Medical School, Tochigi 329-04, Japan
}

Received February 20,1991 Accepted April 18, 1991

\begin{abstract}
We have previously reported that the responsiveness of blood pressure to nitrendipine, a dihydropyridine calcium antagonist, varies with its time of administration. The present study was undertaken to examine whether the diuretic effects of the agent also show diurnal variation. Nitrendipine was given orally at 12 a.m. or 12 p.m. to rats, and urine was collected for 8 hours after administration. The urine volume and urinary sodium excretion were greater at $12 \mathrm{p} . \mathrm{m}$. than at $12 \mathrm{a} . \mathrm{m}$. These data indicate that the cardiovascular as well as renal effects of nitrendipine vary with its time of administration.
\end{abstract}

There is increasing evidence demonstrating time-dependent changes in the effectiveness of cardiovascular agents (1). We already examined the chronopharmacological profiles of nitrendipine, a dihydropyridine calcium antagonist. This study demonstrated that the responsiveness of blood pressure to the agent varies with its administration time (2).

Nitrendipine is frequently used in the treatment of hypertension and the related cardiovascular diseases. Unlike other vasodilators such as hydralazine, prazosin and minoxidil, calcium antagonists are not associated with water and sodium retention, but cause a mild diuresis and natriuresis following, at least, the first dosage $(3,4)$. This pharmacological property of calcium antagonists may be involved in the mechanism responsible for their antihypertensive action. Therefore, it is interesting to examine whether the diuretic effects of nitrendipine also show diurnal variations.

In the present study, nitrendipine was given orally at $12 \mathrm{a} . \mathrm{m}$. or $12 \mathrm{p} . \mathrm{m}$. to rats. The diuretic effects following the agent at 12 a.m. were compared to those when it was given at 12 p.m.

Male Wistar rats (Charles River Laboratory, Kanagawa, Japan) (10-11 weeks old, 300$350 \mathrm{~g}$ ) were maintained for more than 2 weeks under conditions of light from $7 \mathrm{a} . \mathrm{m}$. to 7 p.m. and dark from 7 p.m. to 7 a.m. with free access to food and water.

Since a diuretic effect following a high dose of a calcium antagonist might be masked by a concomitant reduction in blood pressure (5), the first experiment was performed to determine the optimal dosage of nitrendipine for the subsequent study. Rats were randomly divided into two groups. The first group of rats (group $I, n=16$ ) received nitrendipine at 12 a.m., while the second group of animals (group II, $n=16$ ) received the agent at 12 p.m. Three percent body weight (b.w.) of $1 \%$ $\mathrm{NaCl}$ solution was given orally to each group of rats on day 1. Nitrendipine (Yoshitomi Pharmaceutical Industries, Ltd., Osaka, Japan) $(0.5,2.0$ and $10.0 \mathrm{mg} / \mathrm{kg}$ in $3 \%$ b.w. of $1 \% \mathrm{NaCl}$ ) was given orally to each group of 
rats on day 4,7 and 10 , respectively. Urine was collected for 8 hours following vehicle alone or the drug administration. The animals were deprived of food and water for 8 hours following each administration.

Since the $2.0 \mathrm{mg} / \mathrm{kg}$ of nitrendipine was judged as the optimal dosage, this dosage was used for the subsequent experiment. Twenty eight rats were used in the second experiment. Three percent b.w. of $1 \% \mathrm{NaCl}$ solution was given orally at $12 \mathrm{a} . \mathrm{m}$. (or $12 \mathrm{p} . \mathrm{m}$.). Twentyfour hours after the vehicle alone, $2.0 \mathrm{mg} / \mathrm{kg}$ of nitrendipine in $3 \% \mathrm{~b} . \mathrm{w}$. of vehicle was given orally at $12 \mathrm{a} . \mathrm{m}$. (or $12 \mathrm{p} . \mathrm{m}$.). Urine was collected for 8 hours after each administration. The experiment timing was randomly assigned to $12 \mathrm{a} . \mathrm{m}$. or $12 \mathrm{p} . \mathrm{m}$. The washout period between the two sets of experiments was 2.5 days.

Urinary sodium concentration was determined by flame photometry (Flame Photometer 775-A, Hitachi, Tokyo, Japan).

The results are expressed as the mean \pm S.E. Data were analyzed by analysis of variance and the Wholly-Significant-Difference Method.

First experiment (Table 1): Urine volume and urinary sodium excretion increased dose- dependently following 0.5 and $2.0 \mathrm{mg} / \mathrm{kg}$ of nitrendipine in both trials. However, these diuretic effects of the agent were slightly reduced by a dose of $10.0 \mathrm{mg} / \mathrm{kg}$.

Second experiment (Fig. 1): When 3\% b.w. of $\mathrm{NaCl}$ solution was given as a nitrendipine control, no significant difference was observed in urine volume or urinary sodium excretion in the collection period following the $12 \mathrm{a} . \mathrm{m}$. administration (day trial: urine volume, 20.7 $\pm 0.9 \mathrm{ml} / \mathrm{kg} / 8 \mathrm{hr}$; urinary sodium, $3.4 \pm 0.1$ $\mathrm{mEq} / \mathrm{kg} / 8 \mathrm{hr}$ ) compared to the collection period beginning at $12 \mathrm{p} . \mathrm{m}$. (night trial: urine volume, $19.9 \pm 1.1 \mathrm{ml} / \mathrm{kg} / 8 \mathrm{hr}$; urinary sodium, $3.7 \pm 0.2 \mathrm{mEq} / \mathrm{kg} / 8 \mathrm{hr}$ ). Urine volume and urinary sodium excretion increased after 2.0 $\mathrm{mg} / \mathrm{kg}$ of nitrendipine in the day (urine volume, $24.8 \pm 1.0 \mathrm{ml} / \mathrm{kg} / 8 \mathrm{hr}$; urinary sodium, $4.0 \pm 0.2 \mathrm{mEq} / \mathrm{kg} / 8 \mathrm{hr}$ ) and night (urine volume, $28.0 \pm 1.0 \mathrm{ml} / \mathrm{kg} / 8 \mathrm{hr}$; urinary sodium, $5.0 \pm 0.1 \mathrm{mEq} / \mathrm{kg} / 8 \mathrm{hr}$ ) trials. These parameters following the agent were significantly greater at 12 p.m. than at 12 a.m.

It is known that a decrease in blood pressure in itself exerts an antinatriuretic effect (6). Thus, a relatively small dose of nitrendipine, which might not cause a large reduction in blood pressure, must be employed when the

Table 1. Urine volume and urinary sodium excretion following administration of nitrendipine in rats

\begin{tabular}{|c|c|c|c|c|c|c|}
\hline \multirow{2}{*}{ Group } & \multirow{2}{*}{$\begin{array}{l}\text { Dosing } \\
\text { time }\end{array}$} & \multirow{2}{*}{ Parameter } & \multicolumn{4}{|c|}{ Treatment } \\
\hline & & & vehicle & $\mathrm{N}-0.5 \mathrm{mg}$ & $\mathrm{N}-2.0 \mathrm{mg}$ & $\mathrm{N}-10.0 \mathrm{mg}$ \\
\hline \multirow{2}{*}{$\mathrm{I}=16$} & \multirow{2}{*}{12 a.m. } & $\begin{array}{l}\text { urine volume, } \\
\mathrm{ml} / \mathrm{kg} / 8 \mathrm{hr}\end{array}$ & $22.6 \pm 1.2$ & $25.4 \pm 1.1^{*}$ & $27.4 \pm 0.8^{* *}$ & $25.1 \pm 1.3$ \\
\hline & & $\begin{array}{l}\text { urinary sodium, } \\
\mathrm{mEq} / \mathrm{kg} / 8 \mathrm{hr}\end{array}$ & $3.3 \pm 0.2$ & $3.6 \pm 0.1$ & $4.2 \pm 0.1^{* *}$ & $3.9 \pm 0.2^{* *}$ \\
\hline \multirow{2}{*}{$\begin{array}{c}\mathrm{II} \\
\mathrm{n}=16\end{array}$} & \multirow{2}{*}{12 p.m. } & $\begin{array}{l}\text { urine volume, } \\
\mathrm{ml} / \mathrm{kg} / 8 \mathrm{hr}\end{array}$ & $19.9 \pm 1.7$ & $22.6 \pm 1.4$ & $28.6 \pm 1.9^{* *}$ & $24.2 \pm 1.1$ \\
\hline & & $\begin{array}{l}\text { urinary sodium, } \\
\mathrm{mEq} / \mathrm{kg} / 8 \mathrm{hr}\end{array}$ & $4.4 \pm 0.3$ & $4.9 \pm 0.3^{*}$ & $5.8 \pm 0.3^{* *}$ & $5.3 \pm 0.3^{* *}$ \\
\hline
\end{tabular}

Mean \pm S.E. The agent was given orally to group I at $12 \mathrm{a} . \mathrm{m}$. and to group II at $12 \mathrm{p}$. m. Urine was collected during 8 hours after nitrendipine, vehicle $=3 \%$ body weight (b.w.) of $1 \% \mathrm{NaCl}$ solution. $\mathrm{N}-0.5 \mathrm{mg}$, $\mathrm{N}-2.0 \mathrm{mg}$ or $\mathrm{N}-10.0 \mathrm{mg}=$ nitrendipine $0.5,2.0$ or $10.0 \mathrm{mg} / \mathrm{kg}$ in $3 \%$ b.w. of $1 \% \mathrm{NaCl}$ solution, respectively. $*=\mathrm{P}<0.05,{ }^{* *}=\mathrm{P}<0.01$ compared to vehicle. 

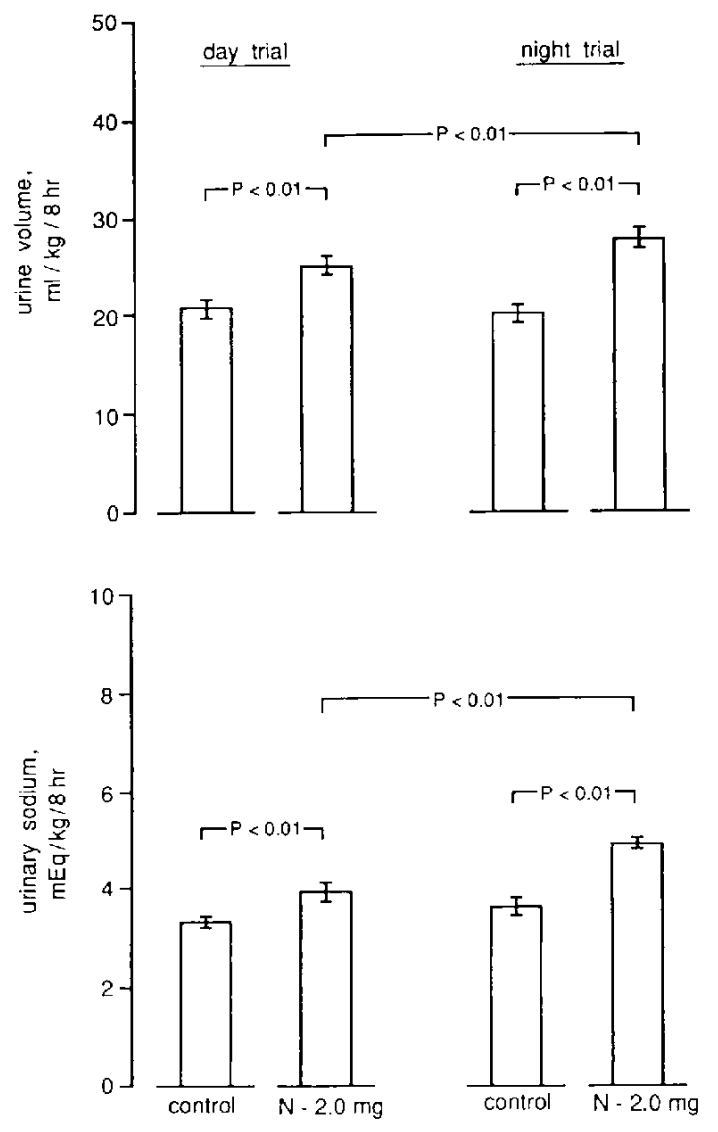

Fig. 1. Urine volume and urinary sodium excretion following oral administration of nitrendipine at 12 a.m. (day trial) or 12 p.m. (night trial) in rats. Mean \pm S.E., $\mathrm{N}=28$. Urine was collected during 8 hours after nitrendipine. Control $=3 \%$ b.w. of $1 \% \mathrm{NaCl}$ solution. $\mathrm{N}-2.0 \mathrm{mg}=$ nitrendipine $2.0 \mathrm{mg} / \mathrm{kg}$ in $3 \%$ b.w. of $1 \%$ $\mathrm{NaCl}$ solution.

diuretic profiles of the agent are examined. Previous studies using normotensive Wistar rats (7) have demonstrated that the mean reductions in blood pressure following 1.0 and $3.1 \mathrm{mg} / \mathrm{kg}$ of nitrendipine were small (4 $\mathrm{mmHg}: 114 \rightarrow 110 \mathrm{mmHg}$, and $7 \mathrm{mmHg}: 119$ $\rightarrow 112 \mathrm{mmHg}$, respectively) while the reduction after $10.0 \mathrm{mg} / \mathrm{kg}$ of the agent was large $(22 \mathrm{mmHg}: 117 \rightarrow 95 \mathrm{mmHg}$ ). These data indicate that the diuretic effects of $10.0 \mathrm{mg} / \mathrm{kg}$ of nitrendipine may be partly offset by a concomitant hemodynamic change. In fact, the present study showed that the pharmacological effects of nitrendipine are blunted at the higher dose $(10.0 \mathrm{mg} / \mathrm{kg})$. On the other hand, its diuretic effects were small at a dose of $0.5 \mathrm{mg} / \mathrm{kg}$. Therefore, $2.0 \mathrm{mg} / \mathrm{kg}$ of nitrendipine was used for the subsequent chronopharmacological study.

Our previous studies have demonstrated that the responsiveness of blood pressure to nitrendipine after the morning dose is greater than that after the evening dosage in human subjects (2). The present study was undertaken to extent this chronopharmacological observation to other pharmacological effects of nitrendipine in saline loaded rats. The present study showed that the diuretic and natriuretic effects of nitrendipine are greater when it is administered at $12 \mathrm{p} . \mathrm{m}$. corresponding to the rat's awake period than when it is administered at $12 \mathrm{a} . \mathrm{m}$. which is their sleep period. Based on these findings, it is anticipated that the cardiovascular as well as renal effects of nitrendipine vary with its time of administration.

Nitrendipine inhibits directly proximal sodium and water reabsorption $(8,9)$ whose mechanisms are still unknown. In addition, saline loading itself causes a mild diuresis and natriuresis by a multifactorial mechanism involving renal, hormonal and physical factors $(10-12)$. Therefore, the enhanced renal response following nitrendipine is likely to be the results of the direct renal tubular effect modified by its effect on the mechanisms involved in the saline-induced diuresis.

The potential mechanisms by which the renal response to nitrendipine shows diurnal variation are as follows: 1) The plasma concentration of nitrendipine varies with its time of dosing. Temporal variation of plasma concentration of the agent has already been documented (2). 2) The susceptibility of renal tissues to nitrendipine shows diurnal changes. A similar chronopharmacological property has also been reported for trichlormethiazide (13). Finally, renal and hormonal functions involved in the regulation of water and electrolyte homeostasis exhibit circadian changes $(14,15)$, and consequently influence the renal effects of 
nitrendipine. The present study is unable to rule out any of these possibilities, and further studies are needed to evaluate them.

\section{Acknowledgment}

We thank Yoshitomi Pharmaceutical Industries, Ltd. for the supply of nitrendipine.

\section{REFERENCES}

1 Lemmer, B.: The chronopharmacology of cardiovascular medications. In Annual Review of Chronopharmacology 2, Edited by Reinberg, A., Smolensky, M. and Labrecque, G., p. 199-228, Pergamon Press, London (1986)

2 Fujimura, A., Ohashi, K., Sugimoto, K., Kumagai, Y. and Ebihara, A.: Chronopharmacological study of nitrendipine in healthy subjects. $\mathbf{J}$. Clin. Pharmacol. 29, $909-915$ (1989)

3 Nagao, T., Yamaguchi, I., Narita, H. and Nakajima, H.: Calcium entry blockers: antihypertensive and natriuretic effects in experimental animals. Am. J. Cardiol. 56, $56 \mathrm{H}-61 \mathrm{H}$ (1985)

4 Ritz, E., Schmid, M., Ji-Zhen, G. and Mann, J.: Salt and the action of calcium antagonists. J. Cardiovasc. Pharmacol. 12, Supp. 6, S53-S56 (1988)

5 Johns, E.J.: The influence of diltiazem and nifedipine on renal function in the rat. Br. J. Pharmacol. 84, 707-713 (1985)

6 Hall, J.E., Granger, J.P., Hester, R.L. and Montani, J.P.: Mechanisms of sodium balance in hypertension: role of pressure natriuresis. $\mathbf{J}$. Hypertens. 4, Supp. 4, S57-S65 (1986)

7 Stoepel, K., Heise, A. and Kazda, S.: Pharmaco- logical studies of the antihypertensive effect of nitrendipine. Arzneimittelforschung 31, 2056-2061 (1981)

8 Häberle, D.A., Kawata, T. and Davis, J.M.: The site of action of nitrendipine in the rat kidney. $\mathrm{J}$. Cardiovasc. Pharmacol. 9, Supp. 1, S17-S23 (1987)

9 Johns, E.J. and Manitus, J.: The renal actions of nitrendipine and its influence on the neural regulation of calcium and sodium reabsorption in the rat. J. Cardiovasc. Pharmacol. 9, Supp. 1, S49-S56 (1987)

10 Knox, F.G. and Haas, J.A.: Factors influencing renal sodium reabsorption in volume expansion. Rev. Physiol. Biochem. Pharmacol. 92, 75-113 (1982)

11 Raff, H., Shinsako, J., Wade, C.E., Keil, L.C. and Dallman, M.F.: Acute volume expansion decreases adrenocortical sensitivity to ACTH and angiotensin H. Am. J. Physiol. 249, R611-R616 (1985)

12 Brace, R.A., Miner, L.K., Siderowf, A.D. and Cheung, C.Y.: Fetal and adult urine flow and ANF responses to vascular volume expansion. Am. J. Physiol. 255, R846-R850 (1988)

13 Fujimura, A., Ohira, H., Shiga, T., Ohashi, K. and Ebihara, A.: Chronopharmacology of trichlormethiazide in rats. Japan. J. Pharmacol. 55, 294298 (1991)

14 Minors, D.S. and Waterhouse, J.M.: Circadian Rhythms and the Human. Wright.PSG, Bristol (1981)

15 Reinberg, A. and Smolensky, M.H.: Biological Rhythms and Medicine. Springer-Verlag, New York (1983) 